\title{
Analysis of Juridical Legal Protection of Women Reproductive Health in Family Planning: A Research Study in Batam City
}

Mediheryanto ${ }^{*}$, Jemmy Rumengan ${ }^{2}$, Fadlan ${ }^{3}$

${ }^{1}$ Student of Master of Law Study Program Faculty of Law Universitas Batam Batam- Indonesia

${ }^{2,3}$ Lecturer of Faculty of Law, Universitas Batam Batam- Indonesia

DOI: $\underline{10.36348 / \text { sijlcj.2020.v03i07.001 }}$

| Received: 02.07.2020 | Accepted: 09.07.2020 | Published: 12.07.2020

*Corresponding author: Mediheryanto

Abstract

Protection of women's reproductive health law has been set out in Law No. 36 the year 2009 and specifically set out in law number 52 the Year 2009, but not yet well implemented. In the declaration of the International Conference on Population and Development is also recognized the right of reproductive women, the right of individuals to determine when having children, the number of children and the distance between children who are medically healthy, free from discrimination, compulsion/violence and do not contradict religious norms. Health services in the family planning related to the arrangement of pregnancy using contraceptives, for this often occurs problems are the difficulties of knowing the importance of access to services and the low compliance with the operational procedures, then in anticipation, it is necessary efforts with the creation of Minimal service standards, the establishment of a quality care team, the establishment of the operational team health and family planning.

Keywords: Legal Protection, Health, Women, Reproductive, Family Planning.

Copyright @ 2020: This is an open-access article distributed under the terms of the Creative Commons Attribution license which permits unrestricted use, distribution, and reproduction in any medium for non-commercial use (NonCommercial, or CC-BY-NC) provided the original author and source are credited.

\section{INTRODUCTION}

Fundamentally the consequences in the way of health services namely should be more comprehensive, among others by not looking at women as the uterus alone (a woman is not a womb), but as women who have a uterus and are in a cultural social network that does not always pay attention to women's rights [1]. Listen to and pay attention from one of the central variables presented in the title of the journal is the construction of legal protection and reproductive health of women in the family planning. At the International Conference on Population and Development (ICPD) in Cairo in 1994, it was stated that reproductive health is a thorough healthy state, covering the physical, mental and social aspects, and not merely the absence of disease or disorders about the reproductive system, its function or the reproductive process itself. Reproductive rights are certain human rights that have been recognized in national law, international human rights documents, and other relevant United Nations consensus documents. These rights are essentially the recognition of the rights of all couples and individuals to obtain reproductive health services with the highest standards and patient-centered approach. The declaration of the International Conference on Population and Development is also recognized for the reproductive rights of women such as the right of women to determine when having children, the number of children, and the period between two pregnancies. In article 12 of Law No. 7 of 1984 on conversion validation regarding the elimination of any form of disapproval of women (Convention on The Elimination of All Forms of Discrimination against Women), strengthening the provisions of women's access to health care by establishing that women reproductive health is the fundamental right of women. It is in line with the provisions of article 72 of Law No. 36 of 2009 on health, that every Barhak: a) lead a reproductive life and a healthy, safe, and free from compulsion and/or violent sexual life with a legitimate spouse; b) determine the life of its reproduction and free from discrimination, compulsion, and/or violence that respects the sublime values that do not degrade human dignity under the religious norms; c) determine for yourself when and how often to reproduce medically healthy and not contradict the religious norms; d) obtain information, education, and counseling on correct and accountable reproductive health.

Regarding the reproductive health of women in family planning, it is expressly stated in article 78 of the Health Law number 36 the Year 2009, that (1) the 
health services in the family planning are intended for the arrangement of pregnancy for the fertile age couple to form a healthy and intelligent successor generation. From the above conditions, it is clear that reproductive health in the family planning is the right of fertile age to decide for yourself when, how often to produce and regulate the distance between a medically healthy child, free from discrimination, compulsion, and/or violence and not contrary to religious norms. To exercise these rights, they must also take into account the needs of the lives of their children now and in the future, and their responsibilities towards society. These types of contraception can be grouped into contraceptives for men (medical operative men/vasectomy and condoms) and contraceptives for women (medical operative Women/Tubektomi, IUD, Implant, injectable and birth control pills).

Saroha Pinem, stating that the degree of women reproductive health can be assessed from seven indicators: first, maternal mortality rate, second, infant mortality rate; Thirdly, the number of family service coverage plans and participation of men in family planning; Fourth, the number of pregnant mothers with 4 too (too young, too old, too much and too near the distance between births); Fifth, the number of pregnant women or mothers with health problems, especially anemia, and less chronic energy; Sixth, protection for women against infectious diseases; Seventh, male understanding of prevention and transmission of sexually transmitted diseases. Women's reproductive health conditions in Batam city are as follows: 1) maternal mortality rate of 226 per 100,000 live births and infant mortality rate amounting to 7.63 per 1000 live births; 2) $38.38 \%$ of the fertile age pair in the city of Batam and the user method of contraceptives $92.35 \%$ of the users' contraceptives method is women. 3) Many expectant mothers based on the age of high risk of $35.95 \%$, (16.49\% of expectant mothers are under 20 years old and $19.46 \%$ of pregnant women aged over 35 years). Then the number of pregnant mothers based on the number of high-risk children is pregnant women with a total of more than 3 children $4.4 \%$ [2].

From the above conditions can be concluded that the degree of reproductive health of women in Batam city is still very low. Based on the above conditions, clearly showing the weak legal protection of women's reproductive health in the practice of family planning, it is felt necessary to research on the legal protection of women's reproductive health planning in Batam city.

\section{Problem Formulation}

1. How to set up legal and implementation of legal protection against women's reproductive health in family planning?

2. What factors become advocates and constraints as well as efforts to realize legal protection against the health of reproductive women in family planning.

\section{RESEARCH METHOD}

Based on the problems above, the specifics of this research, the authors implement the sociological normative legal research which is supported by the research method of the normative law with empirical/sociological law studies. The technique of data collection in this research is for primary data conducted with documentary studies and interviews and for secondary data is conducted with the study of primary, secondary, and tertiary legal materials. The method of analysis used in the study is a qualitative analysis method; all data obtained or collected edited, processed, and arranged in a systematic and then analyzed qualitatively to be obtained clarity of problems that will be discussed.

\section{DISCUSSION \\ Legal arrangements}

Legal arrangements in this document include the construction of legal reproductive health and family planning, the arrangement of pregnancy, and the standardization of family planning services.

\section{Construction of reproductive health law and family planning}

As a legal state then everything in Indonesia must be based on the law (legal basis). The law is a legal product that applies to the public or individuals [3]. The arrangement of reproductive health law in Indonesia, in the perspective of a positive legal reference, is as stipulated in the law number 36 the year 2009 about the health that empirically in the field, commonly referred to as health law and specifically related to the control of population growth is governed in Law number 52 the year 2009 on the development of occupation and family development empirically in the field, usually called the population law. The legal protection arrangement of women reproductive health in the family planning is already very relevant to the efforts to realize the health of reproductive which is human rights and is one element of welfare that must be realized according to the ideals of Indonesian nation as mentioned in Pancasila and the opening of the Constitution of the Republic of Indonesia year 1945. More firmly the legal arrangements on reproductive health and family planning are in order in article 14 and 48 paragraph (2) of the Health Law number 36 the Year 2009 and article 20 of the Population Act number 52 the Year 2009, which explicitly confirms: Article 14: (1) The government is responsible for planning, organizing, applying, building, and supervising the implementation of health efforts that are evenly and affordable by the community. (2) The responsibility of the Government as referred to in paragraph (1) is specified in public service. Article 48: (1) Implementation of health efforts carried out through activities including reproductive health and family planning. Article 20: That to realize the population grows balanced and family quality; the government organized a family planning program. 
Based on the provisions of the fundamental nature especially with the legal basis and/or legal arrangements regarding reproductive health and family planning in principle the implementation of reproductive health services and family planning throughout the territory of the Republic of Indonesia, is the burden and obligation of the government in conducting public services sustainably to realize the population grows balanced and quality families. Reproduction rights in the family planning owned by the fertile age pair, as affirmed in article 72 and article 78 paragraph (2) of health Law number 36 the year 2009 is the right to decide for yourself when, how often would you like to produce and regulate the distance between children who are medically healthy, free from discrimination, compulsion, and/or violence and do not contradict the religious norms, using the methods, tools, and contraceptives to form a healthy and intelligent successor generation. To exercise the right of the PUS should be given information, education, and accountable counseling. If women's reproductive health is disrupted then in the long term it will interfere with the overall quality of human life [4].

\section{Pregnancy setting}

Pregnancy settings that correspond to healthy standards medically are pregnant at age, with an ideal distance and amount. The ideal age to conceive and give birth is between 20-35 years, in consideration that: (1) in general the age of fewer than 20 years, the uterus and pelvis and blood circulation around it have not been developed perfectly, so it will likely have difficulties in childbirth and experiencing greater pregnancy poisoning; (b) After 35 years of age, health and condition of the mother's womb have decreased, so there is a possibility of prolonged labor, bleeding and the risk of defects in the infants they contain [5]. The concept of childbirth distance in the Qoran at Surah AlBaqarah verses 223 and Surah Luqman verse 14 on the recommendation of breastfeeding the child for two years. In line with these verses, there is a recommendation that mothers who are breastfeeding are not pregnant because it will interfere with the health of mothers, children who are being infiltrated, and fetuses in the womb. Mothers who are breastfeeding and pregnant, then the mother's food intake will be divided into herself, the babies who are being fed, and the fetus they contain. The population agency and the National Planning Family (BKKBN) advise the ideal distance between birth and subsequent pregnancies at least 24 36 months, by the recommendations of the World Health Organization (WHO). Determining the number of children who want is a human right owned by a married couple, but too often pregnant and childbirth (mothers once pregnant and childbirth more than three times) including a high-risk pregnancy group, where the mother can experience impaired reproductive health conditions, the position of the baby's positions in the content (latitude) can cause the occurrence of uterine tear, long-lasting childbirth, children's growth and development is less than optimal, adding to the family economic burden, lack of time for mothers to care for him and the endurance of the mother's body decreases so that the mother is susceptible to disease [5].

\section{Standardization of family planning services}

The central government (Ministry of Health and $\mathrm{BKKBN}$ ) has drafted the standardization of family planning services to improve the access and quality of family planning services [6]. Family planning service standards include the requirements of health care facilities and operational standards of service.

(1) Requirements for health services facilities.

Health care facility requirements include the type and number of health facilities, health workers, types of health, contraceptives, and financing.

Table-1: Types of health facilities

\begin{tabular}{|l|l|l|}
\hline \multirow{2}{*}{ No } & \multicolumn{2}{|c|}{ Types of health facilities } \\
\cline { 2 - 3 } & \multicolumn{1}{|c|}{ FKTP } & \multicolumn{1}{|c|}{ FRKTL } \\
\hline 1 & The health center & General Hospital \\
\hline 2 & Doctor's practice & Special Hospital \\
\hline 3 & Pratama Clinic & Primary or equivalent clinic \\
\hline 4 & Pratama D-level hospital or equivalent & \\
\hline
\end{tabular}

Source: Minister of Health Regulation Number 71 the Year 2013

Government Regulation number 47 of 2016 concerning health service facilities, that for the equitable distribution of health service facilities, the regional government is required to provide hospitals, independent practice facilities for health workers, clinics under community needs, and health centers in each District. Required health workers based on family planning service methods are health service personnel who have the competence to do counseling, family planning pill services and family planning injections, condoms (doctors, midwives, and nurses), IUDs and
Implants (Doctors and Midwives who have received training for IUD and Implant Installation), Vasectomy (Urologist/Surgical Specialist/Physician who has been trained to serve vasectomy) Tubectomy Minilaparatomi (Obstetrics and Gynecology Specialist) and Laparoscopic Tubal occlusion Tubectomy (Obstetrician and Obstetrician Specialist) (Minister of Health Regulation No. 71/2013) Types of family planning services that are required include the Counseling Kit (ABPK), BP3K / KB Service Book Standardization, Tensimeter, States cope, Weight Scales, Gynecological 
Chair/table, Sterilisator, IUD KIT, Revomal Implant Kit, VTP Kit, Minilaparatomi and Laparoscopy. Then the contraceptives required include Condoms, PIL KB 1 Combination (Levonorgestrel $0.150 \mathrm{mg}$ and Ethinyl Estradiol $0.030 \mathrm{mg}$ ), KB injections 1 Three months (Medroxyprogesterone acetate $150 \mathrm{mg} \mathrm{/} 3 \mathrm{ml}$ ), Implants/Lower Skin Contraception (AKBK) / implant $\mathrm{KB}$ II Plus inserter (Levonorgestrel), IUD/ Contraception in the Uterus (IUD) namely Copper $\mathrm{Cu} \mathrm{T}$ $380 \mathrm{~A}$ and new contraceptive devices and drugs according to government policy. (Minister of Health Regulation Number 71 the Year 2013). Funding for family planning services for installing IUDs, implants, injections, MOP/vasectomy, and handling complications of postpartum birth control, sourced from BPJS (Permenkes RI Number 64 of 2016).

\section{(2) Standard Operating Procedure (SOP).}

SOP is a written guideline used to encourage or move a group to achieve organizational goals and is a procedure for standardized stages and must be passed to complete a particular work process. The purpose of the SOP is for officers to maintain consistency and level of performance of officers or teams in the organization or work unit, know obvious the roles and functions of each position in the organization, clarify the workflow, authority, and responsibilities of health workers related to protecting the organization, work units and officers from malpractice or other administrative errors and to avoid failures or errors, duplication, and documentation. While the function of the SOP is to facilitate the work of employees or work teams, as a legal basis for irregularities, to know the obstacles and easily tracked, directing officers to be equally disciplined and work and as a guide in carrying out routine work [3]. This arrangement is the basis for providing legal protection for women's reproductive health in family planning. SOP in family planning services, including counseling, screening, making informed consent, and medical treatment.

\section{Implementation of Women's Reproductive Health Protection Laws in Family Planning}

Legal protection is to protect human rights that are harmed by others and the protection is given to the community so that they can enjoy all the rights provided by law [11]. Then, Phillipus M. Hadjon emphasized that legal protection for the people was preventive and repressive government action. Preventive legal protection aims to prevent disputes, which direct government actions to be careful in making decisions based on discretion, and repressive protection aims to resolve disputes, including handling in judicial institutions [8]. Two concepts of protection above, it is clear that the legal protection of women's reproductive health in family planning is directed more towards preventive measures, namely efforts to prevent the reproductive rights of women in family planning from being fulfilled. The law must protect all parties by their legal status because everyone has the same position before the law. Reproductive rights in family planning owned by the fertile age couple, including the right to obtain information and education, the right to use, and choose contraception to be used and the right to get quality family planning access and services to realize the greatest possible welfare for family.

In the attachment of Law Number 23, 2014 concerning Regional Government, in letter N, namely the division of government affairs in the Population and Family Planning Control Division, it is stated that the regency/city government is responsible for implementing communication, information and education services, control and the distribution of contraceptive devices and drug needs as well as the implementation of family planning services and empowerment and enhancing the participation of community organizations at the regency/city level in the implementation of family planning services and fostering. From the above provisions, it is clear that the Batam city government is responsible for fulfilling the reproductive rights of PUS in family planning.

\section{Rights to the KIE service}

Related to the fulfillment of the rights to the KIE service, can be measured by the level of knowledge of PUS to reproductive health and family planning. The level of knowledge of the PUS in outreach and counseling activities, as follows: 1) know in passing (Awareness), individuals know of the existence of the $\mathrm{KB}$, but it does not have in-depth information about the nature and specificness of the idea. They are aware of the media and the officers only through group or mass counseling. 2) Interested, individuals begin to pay attention to the issue of $\mathrm{KB}$, in this level individuals want to know more about the $\mathrm{KB}$ earnestly listen to the explanations obtained from the media and officers through the individual KIE/counseling. 3) Evaluation after an individual has sufficient knowledge of the KB, he/she will assess his or her loss of birth for his or her family. 4) The trial, in this stage the individual tries to run the method or way the KB he/she wants [7].

From the results of interviews with 400 PUS, consisting of 200 participants KB and 200 PUS is not a participant of $\mathrm{KB}$, it can be known that the knowledge of PUS based on information sources, as follows $27 \%$ of the media alone, $38.5 \%$ of the officers only (KIE Group/mass), $12 \%$ of the media and officers (KIE/nonclinical counseling 16.5) From the above data, PUS who get information from the media only, officers only and neighbors/friends as much as $71.5 \%$ are the PUS who know a glimpse of reproductive health and $\mathrm{KB}$ and $40 \%$ who directly try to use contraceptives. PUS who gets information from the media and officers as much as $12 \%$ is the PUS who is on the level of interest and $10 \%$ who directly try to use contraceptives. The PUS did not know KB by $16.5 \%$. Thus, the information and education service in the city of Batam has not been able to fulfill the information needs of PUS. With existing 
knowledge, it became the basis for the PUS to assess to harm him and decide to use contraception.

\section{Right to use and choose contraception}

In article 25 paragraph 1 of the Population Law Number 52 the Year 2009, it is stated that the husband and/or wife has the same status, rights, and obligations in carrying out family planning. This means that the husband and wife have the same rights and obligations in using contraception. If related to Article 31 (1) of Law Number 1 of 1974 concerning marriage it is stated that the rights and position of the wife are balanced with the rights and position of the husband in domestic life and social intercourse together in the community. The wife's rights and position are balanced with the rights and position of the husband both in household life and in social relations so that everything in the family can be negotiated and decided together by husband and wife. It is clear that who will use contraception and what contraception will be used must be negotiated and decided by husband and wife. Decisions are made based on consideration of medical aspects and are free from discrimination, coercion, and do not conflict with religious norms. Decision making in the family, who will use contraception and what contraception will be used, can be seen in the following table:

Table-2: Decisions on Use and Choice of Contraception

\begin{tabular}{|c|c|c|c|}
\hline \multirow{2}{*}{ No } & \multirow{2}{*}{ Question categories } & \multicolumn{2}{|c|}{ PUS for family planning participants } \\
\hline & & Number & $\%$ \\
\hline 1 & Husband & 49 & 24,5 \\
\hline 2 & Wife & 18 & 9 \\
\hline 3 & Husband and Wife & 17 & 8,5 \\
\hline 4 & KB on women's affairs & 111 & 55,5 \\
\hline 5 & Parents & 5 & 2,5 \\
\hline & Total & 200 & 100 \\
\hline
\end{tabular}

Source: Results of interviews with 200 PUS

From the table above, it is clear that only $17.5 \%$ of women use contraception on their own volition and the basis of an agreement between husband and wife. From these conditions, the legal reproductive health of women in family planning has not been protected by the existence of existing legislation. In the use and selection of contraception, there is still discrimination and coercion against women. Fertile age pairs in the city of Batam are 233,626 couples. There were $89,654 \mathrm{~KB}$ participants or $38.38 \%$. Permix contraception can be seen in the table below.

Table-3: KB participant in Batam City

\begin{tabular}{|r|l|r|r|}
\hline $\mathbf{N}$ & Mix of contraception & Number & \multicolumn{1}{c|}{$\%$} \\
\hline 1 & IUD & 12,143 & $13,54 \%$ \\
\hline 2 & Medical Operative Women & 2,718 & $3,03 \%$ \\
\hline 3 & Medical Operative Men & 488 & $0,54 \%$ \\
\hline 4 & Condom & 6,375 & $7,11 \%$ \\
\hline 5 & Implant & 8,415 & $9,39 \%$ \\
\hline 6 & Injections & 33,949 & $37,87 \%$ \\
\hline 7 & Pill & 25,630 & $28,59 \%$ \\
\hline & Total & 89,654 & $38,38 \%$ \\
\hline
\end{tabular}

Source: Department of PPPAPPKB in Batam City.

From the table above it can be seen that the users of contraceptive methods $92.35 \%$ users of contraceptive methods are women (IUD, MOW, MOP, Implant, Injection, and Pill). While men only reached $7.65 \%$, namely MOP, and condoms.

\section{Fulfillment of KB Service Access and Quality}

The implementation of family planning services must be by the standardization of family planning services that are carried out by health facilities that meet the requirements and are carried out following the SOP.

(1) Fulfillment of KB Service Access.

In the city of Batam, there are 460 health facilities and registered and can conduct family planning services as many as 437 health facilities with the classification of family planning services in each health service facility can be seen in the following table. 
Table-4: Classification of family planning services in health service facilities

\begin{tabular}{|l|l|l|}
\hline No & Classification & Number \\
\hline 1 & Simple & 120 \\
\hline 2 & Complete & 310 \\
\hline 3 & Perfect & 7 \\
\hline 4 & Plenary & 0 \\
\hline Total & & 29 \\
\hline
\end{tabular}

Source: Interview Results

From the table above it can be seen that of the 437 health facilities in Batam, 120 health facilities are available health service personnel who have the competence to do counseling, delivery of birth control pills, family planning injections, condoms, prevention of side effects and complications according to ability health facilities and referral efforts. 310 health facilities available health service personnel have the competence to do counseling, providing birth control pills, family planning injections, condoms, IUDs, Implants, prevention of side effects, and complications under the ability of health facilities and referral efforts. Seven health facilities available by health service personnel have the competence to provide counseling, provision of birth control pills, family planning injections, condoms, IUDs, Implants, Tubectomies, prevention of side effects, and complications under the ability of health facilities and referral efforts. Apart from that, all the above health facilities already have supporting facilities for family planning services (Minutes of the results of the stocktaking, 2020) and contraception following the classification of family planning services for each health facility. (Results of an interview with Ms. Umiyati, Head of the Batam City DPPPAPPKB, April 21, 2020).

Table-5: Perception of PUS of family planning participants about access rights to service facilities.

\begin{tabular}{|l|l|r|r|}
\hline No & Access to family planning services & \multicolumn{1}{|c|}{ N } & Percentage \\
\hline 1 & Not easy & 10 & 555 \\
\hline 2 & Quite easy & 50 & 25 \\
\hline 3 & Easy & 120 & 60 \\
\hline 4 & Very easy & 20 & 10 \\
\hline \multicolumn{2}{|c|}{ Total } & 200 & 100 \\
\hline
\end{tabular}

Source: Results of interviews with 200 PUS KB participants

From the table above, it is clear that $60 \%$ of PUS's have easy access to family planning services and $5 \%$ do not have easy access to family planning services. It is not easy to get access to family planning services in Muara Padang, Galang and Bulang sub-districts because each of these districts only has one health facility that is included in the complete classification of family planning services. Then participants served in health facilities in the city of Batam in 2019, as many as 11,899 participants, with details of $25.66 \%$ in government health service facilities (RSUD, RSOB, and Health center) and $74.34 \%$ in private health service facilities, not only that the source of funding in implementation of family planning services, $26.35 \%$ of BPJS and $74.80 \%$ Non-BPJS (1.1\% of BKKBN and $73.7 \%$ of independent $\mathrm{KB}$ participants). In general, the reason for the low number of family planning services that use funding originating from BPJS is because the claim process is complicated and the disbursement takes a long time. Costs charged to family planning participants are only for services because contraception is sourced from DPPPPPB in Batam city. Whereas at the health center prefer to apply the rate set in Perda No. 7 of 2012 concerning Health Service Levies at the Batam City Health Center. (Results of interviews with 29 Hospitals, 20 Health center, 56 Clinics, and 241 Independent Practice Midwives, March 20-30, 2020).
(2) Fulfill the Right to Quality KB Services.

One method for improving service quality is Client Oriented Provider Efficient (COPE). In COPE service quality is not seen as a dimension or aspect, but rather is the right of consumers and the needs of providers. [9]. Consumer rights are the rights to services performed by doctors, midwives and nurses who work under the auspices of service facilities or independent practices, which can fulfill women's rights which include the right to obtain information and education about contraception that is complete and accurate, selfdetermining contraception that will be used and safe and quality service. Family planning services oriented to client satisfaction, SOPs must be performed by health workers, including counseling, screening, informed consent, and medical treatment.

Family planning services in hospitals' government and private, independent practice doctors has been carried out under the SOP. Family planning services at the Clinic and Counseling and screening have been done but not all of them use informed consent. Family planning services at the health center, especially those carried out through mobile services, have not yet fully participated in the SOP because of the limited time and number of PUSs to be served. Family planning services by the Independent Practice Midwife 
specifically for family planning services for Implants and IUDs have been carried out under the SOP, while not all of the family planning services use informed consent. (Results of interviews with 29 hospitals, and 31 independent practice doctors, 56 clinics, 20 health centers, and 241 independent midwives).

Table-6: Use of Informed Consent in Family Planning Services

\begin{tabular}{|l|r|r|r|}
\hline $\begin{array}{l}\text { Medical } \\
\text { facility }\end{array}$ & IUD, MOW, MOP, and Implant & Injection & Number \\
\hline Hospitals & $100 \%$ & $100 \%$ & $100 \%$ \\
\hline Clinics & $97,94 \%$ & $73,44 \%$ & $79,23 \%$ \\
\hline PKM & $82,93 \%$ & $22,47 \%$ & $47,74 \%$ \\
\hline DPM & $100 \%$ & $100 \%$ & $100 \%$ \\
\hline BPM & $100 \%$ & $35 \%$ & $39,45 \%$ \\
\hline Total & $92,62 \%$ & $41,24 \%$ & $52,87 \%$ \\
\hline
\end{tabular}

Source: Routine Statistics for contraceptive services

In addition to the explanation of health care facilities, we need to also see the perception of women participants KB. $32.5 \%$ of women who have been informed and educated about complete and accurate contraception, $65 \%$ of women who choose their contraceptives used, and $89 \%$ of women who feel they have a safe and quality $\mathrm{KB}$ service (results of interviews with $200 \mathrm{~KB}$ participants).

Information and education about complete and accurate contraceptives and choose the contraceptives used, should be obtained through the counseling process and filtering. Safe service is obtained by the service of $\mathrm{KB}$ using informed consent and quality services obtained when medical action is done according to predefined standards. From the explanation above can be the authors concluded that the service of $\mathrm{KB}$ in the city of Batam has not been fully done according to the SOP, therefore can not fulfill the right of the PUS on the service of quality KB.

\section{Constraint factors and efforts to realize the legal protection of reproductive health of women in family planning}

From the previous description, it can be seen that several factors are constraint in the effort to realize the protection of women's reproductive health in planning families. Efforts to address these obstacle factors use the authors' approach to Law No. 23 of 2014 about local governance. As has been outlined in the legal construction of reproductive health and family planning, reproductive health and family planning is part of health. Health enters the group of concurrent government affairs and becomes mandatory governmental affairs relating to basic services. In article 18 of the Local Government Act No. 23 of 2014, affirmed (1) The local government organizer prioritizes the implementation of mandatory governmental affairs relating to basic services. Normative reproductive health and planning family is a priority program of Batam city. Constraints and efforts to be undertaken are: (a) There is no stándar service at a minimum for health care facilities. In article 18 paragraph (2) concerning Local Government Law No. 23 of 2014, affirmed (2) the implementation of basic services on mandatory governmental affairs relating to basic services as referred to in paragraph (1) shall be guided by the minimum standards of service stipulated by the central government. The minimum service standard for hereinafter abbreviated as SPM is the provisions on the type and quality of basic service which is the mandatory government affairs that are entitled to each citizen at the minimum. Essentially the purpose of the generation of SPM is to equalize understanding about operational definitions, performance indicators, size or unit of reference, target, way of calculation, formula, evangelism, denominator, standard, performance unit, and data source [10]. According to the authors should the city government of Batam describe the SPM set by the Health Minister, become the SPM in each of the health facilities that exist in the city of Batam as an effort to achieve the three main missions of regional autonomy and the objective of implementing regional autonomy, mainly to improve the service quantity and quality of reproductive health services in the family planning.

(b) The absence of concrete implementation of article 25 paragraph (1) of the Population Law number 52 the year 2009. The effort required is to utilize the Constitution Court Decree No. 69/PUU-XIII/2015 relating to the marriage agreement.

(c) Still a lack of compliance service personnel against the SOP service KB. Lack of personnel compliance with SOP causes problems related to service quality. The effort that is supposed to be done is how to guarantee all the input elements, processes, and Family Planning service environment and reproductive health under the standards. Therefore, it is necessary to maintain the quality of service in health care facilities. Maintain quality is an effort that is carried out continuously, systematically, objectively, and interactively in establishing problems, causes of quality problems based on predefined standards, establishes 
and implements, and ways of resolving problems according to capabilities, as well as assessing the results achieved and drafting follow-up suggestions [10]. Maintaining the quality of reproductive health service in the family planning, need to be established the city level quality care team and internal health facilities.

\section{CONCLUSION AND SUGGESTION Conclusion}

After conducting data collection and discussion, the following conclusions are made: That the legal provisions concerning the protection of women's reproductive health are fundamentally regulated in Law Number 36 the Year 2009 concerning health and specifically related to population control regulated in Law Number 52 the Year 2009 concerning population development and family development. Existing legal arrangements are still weak and require firmer and clearer legal arrangements relating to reproductive health. The implementation of women's reproductive health protection in family planning in Batam city has not been implemented well. This can be seen from the low knowledge of women about reproductive health in family planning; users of contraception are still dominated by women and still found that the services provided are not under the standardization of family planning services.

Factors constraint to realize the protection of the law of women's reproductive health is the absence of Minimal service standard, the absence of concrete implementation of article 25 paragraphs (1) of the Population Law number 52 the year 2009 and still a lack of compliance service officers on SOP service KB. Efforts to be undertaken include the creation of minimal service standards, utilizing the decree of the Constitutional court No. 69/PUU-XIII/2015 relating to the marriage agreement, and the establishment of the quality care team.

\section{Suggestion}

Based on the conclusions that the author has stated above, it will immediately give the following recommendations: It is recommended that with the existence of such strict regulations in the protection of women's reproductive health that is so complex, the rights and position of the wife are balanced with the rights and positions of the husband both in life the household and in the community so that everything in the family can be negotiated and decided together by husband and wife. It is recommended to maintain the health of fertile age couples who will get married to make a marriage agreement before marriage, at the time of marriage or while in marriage. That it is recommended that a married couple determine their reproductive health by medical standards of health, free from discrimination, coercion, and/or violence, and not contrary to religious norms.

\section{REFERENCE}

1. Imelda Debora Johanna. (2004). Kesehatan \& Hak Reproduksi, FISIP-UI, Jakarta.

2. Badan Kependudukan Keluarga Berencana Nasional. (2018). Pedoman Standarisasi Pelayanan Keluarga Berencana

3. Maskawati. (2018). Hukum Kresehatan Dimensi Etis dan Yuridis Tanggung Jawab Pelayanan Kesehatan, Litera, Yogyakarta.

4. Sururin. (2010). Pendidikan Kesehatan Reproduksi Bagi Calon Pengantin, Pucuk pimpinan Fatayat Nahdatul Ulama, Jakarta.

5. Bkkbn, \& Kementerian, K. (2012). Buku Pedoman Pelaksanaan Jaga Mutu Pelayanan Keluarga Berencana, Jakarta.

6. Aspan, H. (2017). "Good Corporate Governance Principles in the Management of Limited Liability Company. International Journal of Law Reconstruction, 1(1), 87-100.

7. Marmi. (2013). Kesehatan Reproduksi, Pustaka Pelajar, Yogyakarta.

8. M. Hadjon, P. (1987). Perlindungan Hukum Bagi Rakyat Indonesia, PT. Bina Ilmu Surabaya.

9. Ridwan, H. R. (2003). Hukum Administrasi Negara, Universitas Islam Indonesia Press, Yogyakarta.

10. Laksono. (2010). Standar Pelayanan Minimal Kesehatan Sebuah Panduan Formulasi di Tingkat Puskesmas/Kecamatan, Health Advocacy, Surabaya.

11. Raharja, I. A., \& Rumengan, J. (2020). Legal Analysis on Notarial Deed Concerning Transfer of Assets Belonging to Limited Liability Company Conducted by Director Without Prior Approval from General Meeting of Shareholders (Case Study in High Court of Pekanbaru). IJASSH, 01-09. 